\title{
The Manual Dexterity of Nurses and Factors that Affect It
}

\author{
By Yıldız Denat ${ }^{*} \&$ Hürmüs Kuzgun ${ }^{ \pm}$
}

\begin{abstract}
The purpose of this descriptive and analytical study was to define the manual dexterity of nurses and factors that affect it. The sample for this descriptive and analytical study consisted of 96 nurses who worked in an education and research hospital in the south region of Turkey and were willing to participate in the study. The data collection tools were a survey and the Purdue pegboard test. The results of this study indicated that gender and lack of hobby affect hands dexterity and that some types of manual dexterity decreased as age, years of working as a nurse, and BMI increased. The results of this study may constitute a normative data for future studies which would be conducted on this issue.
\end{abstract}

Keywords: Manual dexterity, nursing, Purdue pegboard test

\section{Introduction}

Nursing is a branch of arts and sciences (Denat and Eşer 2006) that require the understanding and application of specialized knowledge and skills to provide comprehensive patient care. Professional nursing practices are founded upon cultural and professional knowledge, clinical and conceptual skill, and the value system of the individual (Denat and Eşer 2006).

Nurses go through an education system that covers cognitive, sensory and psychomotor learning fields during their nursing education (Morgan 2006, Goldsmith et al. 2006, Mete and Uysal 2009). Psychomotor learning has an important place at the stage of implementation of what has been learned during the education process. Psychomotor field comprises skills, movement, muscle movement, and hand manipulation (National Association of EMS Educators 2002, Denat and Eşer 2006). Skill is the ability to perform a task or a group of tasks, applications that require tools and equipment, by using motor functions, at a specially defined level of competence (Mamakl1 2010). Skills primarily include movement-based activities, psychomotor skills can be grouped as skills that require attention, manipulative skills, and skills that require excessive movement. Skills that need attention include attention-based sensitive functions such as IV injection. Manipulative skills are the functions that require eye and arm to work together, as well as manual dexterity (for example physical examination, aspiration, dressing, etc.). As for the skills that require excessive movement include the functions that require movement of large muscle groups (Moore 2001, Denat and Eşer 2006). In many nursing practices, it is important to acquire all of these three groups of psychomotor skills.

\footnotetext{
*Associate Professor, Nursing Faculty, Aydın Adnan Menderes University, Turkey.

${ }^{ \pm}$Research Assistant, Nursing Department, Faculty of Health Sciences, Nevşehir Hacı Bektaş Veli University, Turkey.
} 
In the literature, there are studies on manual dexterity and effective factors in many professions that require hand and eye coordination. When the studies aiming to determine the effect of demographic properties on manual dexterity are examined, Yücel and Bumin (2010) found that hand function decreased significantly with age, and women's manual dexterity was better than men. In another study where the grip strength and anthropometric measurement results were compared according to gender, the difference was found to be significant in favor of men, whereas female students were found to be more successful than the boys in the manual dexterity test (Yücel and Kayıhan 2008). In the study by Çalışkan and Gökbel (1997) which investigated the relations between hand preference, manual dexterity and grip strength in both sexes, left-hand dexterity was observed to decrease as the degree of right-handedness increased. In another study conducted by İlmezli (2011) on manual dexterity, the manual dexterity test performed with the dominant hand was found to be completed in a shorter time than the non-dominant hand, and the manual dexterity of the dominant hand was better than the non-dominant hand. In the study conducted by Genç et al. (2002) which compared the hand functions of musicians and non-musicians, nonmusicians were found to be able to perform manual dexterity tests in a shorter duration than musicians.

In studies conducted in the field of dentistry, Weinstein et al. (1979) determined that general practitioner dentists who completed the skill test in a long time received high scores in restorative quality; Orbak et al. (2002) found that in terms of coordination between two hands and dexterity, left-handed dentists were superior to those who were right-handed, Ojimba et al. (2004) determined the fact that dentistry students' way of sitting and holding tools had a facilitating effect on gaining manual dexterity. Gansky et al. (2004) found that through a manual dexterity test applied to dentistry students, it would not be able to predict the clinical success grade. Besides, Giuliani et al. (2007) found that basic manual dexterity is not required for the selection of dentistry students, and the manual dexterity of students who carry on with the education are significantly improved.

There are also studies in the literature that examine the effect of glove type and thickness on dexterity. As a result of their study, Sawyer and Bennett (2006) found that using nitrile type gloves in jobs requiring fine skills may hinder the skill. Drabek et al. (2010) stated that health workers should wear gloves of appropriate size when performing manual work. Fry et al. (2010) stated that the use of double gloves does not have a significant effect on dexterity and touch sensitivity when compared to cases without gloves or with single gloves; Bensel (1993) stated that preferring the finest glove is the most effective selection for hand performance, as well as chemical protection. Neiburger (1992) also stated that the use of gloves in dental operations significantly reduced dexterity.

In Turkey, relevant studies in the nursing field that the researchers have reached are that of Bakır et al. (2013) which examines the relationship between nursing students' dexterity and nursing course mid-year success grades, as well as the grades received at the entrance exam of nursing school, and that of Kuzgun and Denat (2020) which aims to determine manual dexterity of nursing students and effective factors. As a result of the study by Bakır et al. (2013), manual 
dexterity was found to display no parallels with the knowledge level. Kuzgun and Denat (2020) determined that the manual dexterity of senior nursing students was relatively high, and that girls, those with a normal body structure, and those who chose the profession voluntarily had better manual dexterity.

As is seen, the studies in the field of manual dexterity were about the effect of demographic properties and wearing gloves on manual dexterity, and they mostly focused on dentistry and dentistry students. In the field of nursing, the researchers could not reach a sufficient amount of studies. However, in professions as nursing where hand manipulation is used, manual dexterity and its level of development are important. The purpose of this study was to define the manual dexterity of nurses and factors that affect it.

\section{Methodology}

\section{Design and Sample of the Research}

The purpose of this descriptive and analytical study was to define the manual dexterity of nurses and factors that affect it.

In according to Republic of Turkey Ministry of Health Health Statistics Yearbook 2018 data, the total number of nurses in turkey is 190.499 and the number of nurses working in University teaching and research hospital is 29.263 (Başara et al. 2019). The population of the research consisted of 400 nurses working in a training and research hospital in the southern region of Turkey. This number constitutes $1.4 \%$ of the general population.

In this research, a sample size of $95 \%$ reliability level was estimated using the "G. Power-3.1.9.2" computer program. Based on the study by Kuzgun and Denat (2020), the effect size was calculated as $0.53, \alpha=0.05$, and the total sample size 90 to attain a power level of 0.80 . Taking into account the sample losses, the study was completed with 96 nurses volunteering to participate in the study.

\section{Data Collection Tools}

In the research, the data collection tools were through PurduePegboard Test and a survey form created by scanning the literature (Demirel 2005, Giuliani et al. 2007, Yücel and Kayıhan 2008, Sezer et al. 2009, Bakır et al. 2013).

The survey consisted of two parts; the first part contains introductory information about the participant and questions concerning the factors which are thought to affect manual dexterity. The second part includes the Purdue Pegboard Test results. Introductory information and questions concerning the factors that are thought to affect manual dexterity include age, gender, educational status, the clinic worked in, working experience, dominant hand, the status of suffering from a chronic disease, the status of medication use, existence of a physical case that cause a finger loss or holding and gripping problem, having a hobby, doing sports, the status of voluntarily choosing the profession, and satisfaction with the profession. 
Purdue Pegboard Test was developed by Tiffin and Asher (1948) for measuring manual dexterity. Validity and reliability studies concerning the test have been completed (Tiffin and Asher 1948). The test comprises five subtests: (a) right hand; (b) left hand; (c) both hands; (d) right + left + both hands; (e) assembly. The test board consists of a board with four cups across the top row and two vertical rows comprising 25 small holes towards the center. Each of the two outside cups contains 25 pins; the cup at the immediate left of the center contains 40 washers and the cup at the right of the center contains 20 collars.

Each phase is repeated three times. The mean scores for each subtest consist of the average scores of these 3 applications (Lafayette Instrument 2015).

\section{Data Collection}

The study was completed with 96 nurses volunteering to participate in the study. Before the data collection process, nurses were informed about the aim of the study. The survey was conducted through a face-to-face interview with 96 nurses.

Purdue Pegboard Test is based upon the principle of applying manual skills at a certain time interval. It measures two kinds of skills. The first is the gross motions of the whole hand, fingers, and arms; the other one is the fine manual dexterity which is required in the assembly tasks. The application comprises 4 stages: right hand, left hand, both hands, and the assembly. In general, at the end of the application 4 distinct scores are obtained: right-hand score, left-hand score, both hands score, right hand + left hand + both hands score, and assembly score. The performance of the right-hand subtest requires participants to place as many pins as possible within 30 seconds using their right hands. The left-hand phase is also the same. The score of each of these subtests is the total number of pins placed by each hand within the given time. Both hands subtest is a bimanual test where the participants use both hands simultaneously to place as many pins as possible in both rows in 30 seconds. The score of this subtest is the total number of pairs of pins placed in 30 seconds. For the right hand+left hand+both hands score there is no separate test, it is the arithmetical sum of the scores of the right hand, left hand and both hands subtests. The assembly phase comprises the placement of a nail, washer, ring, and a washer again into a gap. The score of this subtest is the total number of pins, washers, and rings placed using both hands simultaneously in 60 seconds. The data were collected by only one researcher. Data collection took about 20 minutes for each participant

\section{Statistics}

The data were assessed using SPSS version 18.0. Since the data showed normal distribution, the T-test for independent groups, One-Way Analysis of Variance (ANOVA) and Pearson Correlation Analysis were also used for data analysis. For the results, we accepted $\mathrm{p}<0.05$ as statistically significant.

Ethics Approval 
To conduct the study, we obtained approval from the Adnan Menderes University Faculty of Medicine Non-interventional Clinical Research Ethical Committee (Approval no: 53043469-050.04.04) and the informed consent forms were signed earlier by individuals to participate in the research.

\section{Results}

The mean age of the nurses participating in the study was $27.48 \pm 4.52$; $67.7 \%$ of the nurses were female, $84.4 \%$ had bachelor's degree, $38.5 \%$ were working in Surgical Service, and had an average working experience of $60.29 \pm$ 47.95 months (approximately 5 years); $88.5 \%$ of the nurses used their right hand predominantly, $71.9 \%$ of them did not have a chronic disease and $89.6 \%$ of them did not use medication regularly. None of the nurses had a physical problem that would affect their ability to hold and grasp such as finger loss, injury, etc.; 64.6\% did not have any hobbies and $71.9 \%$ did not do sports. $46.9 \%$ of the nurses stated that they preferred the nursing profession voluntarily and $53.1 \%$ stated that they were satisfied with their profession (Table 1).

Table 1. Comparison of the Characteristics of Nurses with their Purdue Pegboard Test Scores

\begin{tabular}{|c|c|c|c|c|c|c|c|c|c|c|c|}
\hline \multirow[b]{3}{*}{ Characteristics } & \multirow[b]{3}{*}{$\mathbf{n}$} & \multicolumn{10}{|c|}{ Phase of test } \\
\hline & & \multicolumn{2}{|c|}{$\begin{array}{l}\text { Dominant } \\
\text { hand }\end{array}$} & \multicolumn{2}{|c|}{$\begin{array}{l}\text { Non-dominant } \\
\text { hand }\end{array}$} & \multicolumn{2}{|c|}{ Both hands } & \multicolumn{2}{|c|}{$\begin{array}{c}\text { Right hand + } \\
\text { left hand + } \\
\text { both hands }\end{array}$} & \multicolumn{2}{|c|}{ Assembly } \\
\hline & & Mean & SD & Mean & SD & Mean & SD & Mean & SD & Mean & SD \\
\hline \multicolumn{12}{|l|}{ Gender } \\
\hline Female & 65 & 19.02 & 1.40 & 17.38 & 1.40 & 14.89 & 1.25 & 51.32 & 3.57 & 42.37 & 6.59 \\
\hline Male & 31 & 18.39 & 1.20 & 16.64 & 1.34 & 14.10 & 1.26 & 49.14 & 3.38 & 38.94 & 7.12 \\
\hline$t / p$ & & \multicolumn{2}{|c|}{$\mathrm{t}=2.15, \mathrm{p}=\mathbf{0 . 0 3}$} & \multicolumn{2}{|c|}{$\mathrm{t}=2.44, \mathrm{p}=0.01$} & \multicolumn{2}{|c|}{$\mathrm{t}=2.90, \mathrm{p}=0.00$} & \multicolumn{2}{|c|}{$\mathrm{t}=2.83, \mathrm{p}=0.00$} & \multicolumn{2}{|c|}{$\mathrm{t}=2.32, \mathrm{p}=0.02$} \\
\hline \multicolumn{12}{|c|}{ Educational Status } \\
\hline $\begin{array}{l}\text { Vocational High } \\
\text { School of Health }\end{array}$ & 15 & 18.53 & 1.18 & 17.08 & 1.59 & 14.53 & 1.03 & 50.26 & 3.47 & 39.77 & 5.08 \\
\hline $\begin{array}{l}\text { Bachelor } \\
\text { Education }\end{array}$ & 81 & 18.87 & 1.40 & 17.15 & 1.39 & 14.66 & 1.35 & 50.68 & 3.68 & 41.53 & 7.20 \\
\hline $\mathbf{t} / \mathbf{p}$ & & \multicolumn{2}{|c|}{$\mathrm{t}=-0.18, \mathrm{p}=0.37$} & \multicolumn{2}{|c|}{$\mathrm{t}=-0.17, \mathrm{p}=0.86$} & \multicolumn{2}{|c|}{$t=-0.36, p=0.71$} & \multicolumn{2}{|c|}{$\mathrm{t}=-0.40, \mathrm{p}=0.68$} & \multicolumn{2}{|c|}{$\mathrm{t}=-0.90, \mathrm{p}=0.36$} \\
\hline \multicolumn{12}{|c|}{ Currently Working Clinic } \\
\hline Intensive Care & 33 & 18.69 & 1.28 & 17:05 & 1.45 & 14.71 & 1.39 & 50.47 & 3.62 & 40.95 & 6.31 \\
\hline Internal Clinics & 37 & 18.81 & 1.44 & 17.21 & 1.30 & 14.54 & 1.29 & 50.61 & 3.61 & 41.37 & 7.77 \\
\hline Surgical Clinics & 26 & 18.99 & 1.40 & 17.15 & 1.57 & 14.68 & 1.24 & 50.81 & 3.83 & 41.49 & 6.60 \\
\hline $\mathbf{F} / \mathbf{p}$ & & \multicolumn{2}{|c|}{$\mathrm{F}=\mathbf{0 . 3 5}, \mathrm{p}=\mathbf{0 . 7 0}$} & \multicolumn{2}{|c|}{$\mathrm{F}=0.10, \mathrm{p}=0.90$} & \multicolumn{2}{|c|}{$\mathrm{F}=0.16, \mathrm{p}=0.84$} & \multicolumn{2}{|c|}{$\mathrm{F}=0.06, \mathrm{p}=0.93$} & \multicolumn{2}{|c|}{$F=0.05, p=0.95$} \\
\hline \multicolumn{12}{|c|}{ Choosing the nursing profession willingly } \\
\hline Yes & 45 & 18.52 & 1.39 & 16.98 & 1.36 & 14.47 & 1.22 & 49.99 & 3.44 & 39.95 & 6.36 \\
\hline No & 26 & 18.86 & 1.29 & 16.86 & 1.43 & 14.52 & 1.31 & 50.29 & 3.55 & 41.80 & 7.30 \\
\hline Partially & 25 & 19.30 & 1.32 & 17.71 & 1.40 & 15.06 & 1.38 & 52.07 & 3.80 & 43.06 & 7.27 \\
\hline $\mathbf{F} / \mathbf{p}$ & & $F=2.67$, & $=0.07$ & $\mathrm{~F}=2.92$, & $=0.05$ & $\mathrm{~F}=\mathbf{1 . 8 0}$, & $=2.87$ & $\mathrm{~F}=\mathbf{2 . 8 7}$, & $=0.06$ & $\mathrm{~F}=1.76$, & 0.17 \\
\hline Being satisfied v & the & irsing pr & fession & & & & & & & & \\
\hline Yes & 51 & 18.87 & 1.36 & 17.32 & 1.21 & 14.74 & 1.23 & 50.95 & 3.27 & 41.08 & 7.13 \\
\hline No & 16 & 18.95 & 1.14 & 17.33 & 1.40 & 14.72 & 1.63 & 51.03 & 3.85 & 42.26 & 6.68 \\
\hline Partially & 29 & 18.66 & 1.52 & 16.71 & 1.70 & 14.42 & 1.24 & 49.80 & 4.11 & 41.02 & 6.86 \\
\hline $\mathbf{F} / \mathbf{p}$ & & $\mathrm{F}=\mathbf{0 . 3 0 ,}$ & $=0.73$ & $F=1.96$, & $=0.14$ & $F=0.58$, & $=0.55$ & $\mathrm{~F}=1.04$, & $=0.35$ & $\mathrm{~F}=0.19$, & $=0.82$ \\
\hline Having & & & & & & & & & & & \\
\hline Yeah & 34 & 18.52 & 1.17 & 16.71 & 1.33 & 14.36 & 1.18 & 49.63 & 3.27 & 39.26 & 7.48 \\
\hline No & 62 & 18.98 & 1.45 & 17.37 & 1.42 & 17.79 & 1.34 & 51.15 & 3.74 & 42.35 & 6.39 \\
\hline$t / p$ & & $\mathrm{t}=-1.58$, & $=0.11$ & $\mathrm{t}=-2.24$ & $=0.02$ & $\mathrm{t}=-\mathbf{1 . 5 3}$, & $=0.12$ & $\mathrm{t}=-1.99$ & $=0.04$ & $\mathrm{t}=-\mathbf{2 . 1 2}$, & 0.03 \\
\hline Doing Sports & & & & & & & & & & & \\
\hline Yes & 27 & 18.81 & 1.39 & 17.18 & 1.59 & 14.60 & 1.05 & 50.57 & 3.65 & 39.99 & 7.36 \\
\hline
\end{tabular}




\begin{tabular}{|c|c|c|c|c|c|c|c|c|c|c|c|}
\hline No & 69 & 18.82 & 1.37 & 17.12 & 1.36 & 14.65 & 1.39 & 50.63 & 3.66 & 41.76 & 6.72 \\
\hline$t / p$ & & \multicolumn{2}{|c|}{$t=-0.04, p=0.96$} & \multicolumn{2}{|c|}{$t=0.16, p=0.86$} & \multicolumn{2}{|c|}{$\mathrm{t}=-0.18, \mathrm{p}=0.85$} & \multicolumn{2}{|c|}{$\mathrm{t}=-0.06, p=0.94$} & \multicolumn{2}{|c|}{$t=-1.12, p=0.26$} \\
\hline
\end{tabular}

Nurses were determined to work for an average of $7.12 \pm 3.12$ hours a day when the Purdue Pegboard Test was applied. The mean dexterity scores of the nurses were $18.82 \pm 1.37$ for the dominant hand, $17.14 \pm 1.42$ for the nondominant hand, $14.64 \pm 1.30$ for both hands, $50.61 \pm 3.64$ for right + left + both hands, and $41.26 \pm 6.92$ for assembly skill.

According to the results of the study, all kinds of mean dexterity scores of female participants were found to be significantly higher than the male, and those who did not have a hobby were found to have higher non-dominant hand, right + left + both hands, and assembly mean scores $(\mathrm{p}<0.05)$ (Table 2$)$.

Table 2. The Relationship between the Characteristics of Nurses and Purdue Pegboard Mean Scores

\begin{tabular}{|l|c|c|c|c|c|c|c|c|c|c|}
\hline & \multicolumn{2}{|c|}{$\begin{array}{c}\text { Dominant } \\
\text { hand }\end{array}$} & \multicolumn{2}{c|}{$\begin{array}{c}\text { Non- } \\
\text { dominant } \\
\text { hand }\end{array}$} & \multicolumn{2}{c|}{ Both hands } & \multicolumn{2}{c|}{$\begin{array}{c}\text { Right hand + } \\
\text { left hand + } \\
\text { both hands }\end{array}$} & \multicolumn{2}{|c|}{ Assembly } \\
\cline { 2 - 12 } & $\mathrm{r}$ & $\mathrm{p}$ & $\mathrm{r}$ & $\mathrm{p}$ & $\mathrm{r}$ & $\mathrm{p}$ & $\mathrm{r}$ & $\mathrm{p}$ & $\mathrm{r}$ & $\mathrm{p}$ \\
\hline Age & -0.18 & 0.07 & -0.15 & 0.13 & -0.22 & $\mathbf{0 . 0 2}$ & -0.21 & $\mathbf{0 . 0 3}$ & -0.24 & $\mathbf{0 . 0 1}$ \\
\hline $\begin{array}{l}\text { Working year } \\
\text { as a nurse }\end{array}$ & -0.21 & $\mathbf{0 . 0 3}$ & -0.17 & 0.09 & -0.23 & $\mathbf{0 . 0 1}$ & -0.23 & $\mathbf{0 . 0 2}$ & -0.31 & $\mathbf{0 . 0 0}$ \\
\hline BMI & -0.34 & $\mathbf{0 . 0 0}$ & -0.16 & 0.11 & -0.23 & $\mathbf{0 . 0 2}$ & -0.28 & $\mathbf{0 . 0 0}$ & -0.31 & $\mathbf{0 . 0 0}$ \\
\hline $\begin{array}{l}\text { Working } \\
\text { duration } \\
\text { when the test } \\
\text { was applied }\end{array}$ & -0.14 & 0.16 & -0.10 & 0.29 & -0.17 & 0.08 & -0.15 & 0.12 & -0.15 & 0.14 \\
\hline
\end{tabular}

A negative correlation was found between the dominant hand mean scores and working duration as a nurse $(\mathrm{r}=-0.21)$, as well as BMI $(\mathrm{r}=-0.35)$. No significant correlation was found between the non-dominant hand dexterity, age, working duration as a nurse, and BMI. A negative correlation was found between both hands dexterity mean scores, age $(\mathrm{r}=-0.22)$, working duration as a nurse $(\mathrm{r}=$ $-0.24)$, and BMI $(\mathrm{r}=-0.24)$. A negative correlation was found between the mean scores of right + left + both hands dexterity, age $(\mathrm{r}=-0.22)$, working duration as a nurse $(r=-0.24)$, and BMI $(r=-0.28)$. A negative correlation was found between the mean scores of assembly skill, age $(r=-0.24)$, working duration as a nurse $(r=$ $-0.31)$, and BMI $(r=-0.31)$.

\section{Discussion}

In the literature, it is emphasized that the genes and genetic structure of the individual play a role in the development and differentiation of the hand. Also the external factors faced by the hand in the development process and the work or the occupation that the individual deals with affect the hand structure (Demirel 2005). In this study, which was carried out to determine the manual dexterity of the nurses and effective factors, the mean manual dexterity scores of nurses were 
found $18.82 \pm 1.37$ for the dominant hand, $17.14 \pm 1.42$ for the non-dominant hand, $14.64 \pm 1.30$ for both hands, $50.61 \pm 3.64$ for right + left + both hands, and $41.26 \pm 6.92$ for assembly skill. In a study conducted to evaluate hand function according to professions, differences were found between office workers and industrial workers in all of the gripping, dexterity and functionality tests; industrial workers were found to have greater hand strength, and lower manual dexterity, while office workers lower hand strength, and greater manual dexterity (Doğan 2012). Besides, in a study by Kuzgun and Denat (2020) which examines the manual dexterity of nursing students, mean dominant hand dexterity scores of the students were found to be $19.16 \pm 1.36$, mean non-dominant hand dexterity scores $17.04 \pm 1.43$, mean both hands dexterity scores $14.58 \pm 1.35$, mean right hand + left hand + both hands dexterity scores $50.70 \pm 4.20$, and mean assembly skill scores $38.55 \pm 6.02$. For every stage of the test, the findings of this study are similar to that of Kuzgun and Denat (2020).

When the effect of age on manual dexterity was analyzed, hand functions were found to decrease significantly with age (Yücel and Bumin 2010), and as a result of this study a significant negative relation was found between age, both hands, right hand + left hand + both hands, and assembly mean scores. According to the result of the study, as the age increases the manual dexterity of individuals can be said to decrease. In the study, all kinds of manual dexterity mean scores of female participants were found to be significantly higher than that of the male; many other studies also determined that women's manual dexterity is better than that of men (Dokuztuğ et al. 1991, Agnew et al. 1988, Çakıt 2008, Yücel and Bumin 2010, Yücel and Kayıhan 2008, Kuzgun and Denat 2020).

When the literature was examined, manual dexterity was observed to be associated with many factors such as hand anthropometry, hand preference, gender, and demographic properties; there was not a sufficient amount of studies on hobby/pursuit factor, a limited number of studies on sports factor was encountered by the researchers as well. Hobby/pursuit means a work, activity or occupation that someone does voluntarily and with pleasure. ${ }^{1}$ It is an activity that is repeated at different time intervals depending on the will of the individual, and repetitive motor activities are well-known to form the basis for motor learning (Higgins et al. 2005, Beydoğan 2008). For this reason, in our study, the hobbies/pursuits were examined which the nurses were interested in and which are thought likely to improve their manual dexterity. As a result of the study, those who do not have a hobby were found to have higher dominant hand, right + left + both hands and assembly mean scores $(\mathrm{p}<0.05)$, and doing sports was found not to cause any change in manual dexterity. When similar studies are examined, considering the relationship between sports and manual dexterity, Soyupek et al. (2006) found that aerobic exercise had a positive effect on dexterity, while Gündoğan et al. (2009) determined that short-term motor activity positively affected the pace of manual dexterity. In another study conducted by Ölçücü et al. (2010), tennis training was found to produce important developments in nondominant hand coordination. As for the studies comparing music and manual

\footnotetext{
${ }^{1}$ http://www.tdk.gov.tr.
} 
dexterity, Wagner (1988) found that pianists had higher manual mobility compared to those who do not actively engage in music, Genç et al. (2002) found that nonmusicians managed to perform manual dexterity tests in a shorter duration than musicians. The literature shows that sports activities and musical instrument playing are the most examined factors regarding their relationship with manual dexterity. The results of this study displayed exactly the opposite effect. Most of the nurses participating in the study are not interested in any hobby or sports activities, while those who are interested in such activities focus rather on applications that require gross motor activities.

When the effect of years working as a nurse on manual dexterity was examined, a negative relationship was found between working years as a nurse, dominant hand, both hands, right hand + left hand + both hands, and assembly mean scores. In the literature, there were not found any studies examining the effects of working duration in different occupations on manual dexterity, whereas in the studies conducted with nursing and dentistry students there are findings showing that as the education progresses the manual dexterity of students develops (Bakır et al. 2013, Kuzgun and Denat 2020, Giuliani et al. 2007). In the training processes of practical occupations, the manual dexterity of students improves because of a certain degree of discipline and repeated applications that the training process entails, while in the professional practice no short-term changes are observed in manual dexterity which is thought to arise from a decrease in the repetitive improving activities. Indeed, the nurses who participated in the study had approximately 5-years of working. This fact, limits arriving at a general judgment on the effect of working duration on manual dexterity. Conducting and evaluating similar studies with nurses who have a longer-term working experience could be recommended.

In the study, a significant negative relationship was found between the BMI of the nurses and their dominant hand, both hands, right + left + both hands, and assembly scores. In the study by Kuzgun and Denat (2020), nursing students with a normal body type $\left(18.5-24.99 \mathrm{~kg} / \mathrm{m}^{2}\right)$ were determined to have greater assembly mean scores than the ones with a pre-obese body type $\left(>25.00 \mathrm{~kg} / \mathrm{m}^{2}\right)$. In their study, D'Hondt et al. (2009) found that obese students' general motor skills (including manual dexterity) were lower than that of normal weight and pre-obese students. This study supports other research results in this respect, showing that manual dexterity decreases as the BMI increases.

Educational status, the clinic worked in, the status of voluntarily choosing the profession, the satisfaction with the occupation, and the working year at the time of the application of the test were determined not to cause any significant change in the manual dexterity of nurses. In the literature, no other study was encountered which investigates the relationship between willingly choosing the profession and manual dexterity. However, psychomotor skills are stated to require not only the use of muscles in a coordinated way but also the verbal knowledge about the skill, strategy, as well as the enjoyment during the application of the skill (Senemoğlu 2011). In the study conducted with the nursing students by Kuzgun and Denat (2020), the students who had voluntarily chosen the profession had significantly higher dominant hand scores than those who had not. The results of this study do 
not support the literature. This is thought to be due to the fact that the nurses in the population were young and had an average of 5-year working experience, and that most of the nurses had chosen the profession voluntarily or partially voluntarily, and were satisfied with the profession.

\section{Conclusion}

As the conclusion of the study, gender and not having a hobby were found to affect the manual dexterity; certain kinds of manual dexterity were determined to decrease as the age, years of working as a nurse, and BMI increase. According to the results of the study, the assignment of female, young nurses with normal (or below) body mass index could be recommended in jobs that require manual dexterity more. The results of this study might constitute normative data for future studies on the subject. Besides, repeating the study with nurses having longer-term work experience and working in different institutions could also be recommended.

\section{References}

Agnew J, Bolla-Wilson K, Kawas CH, Bleecker ML (1988) Purdue pegboard age and sex norms for people 40 years old and older. Developmental Neuropsychology 4(1): 2935.

Bakır B, Koçak N, Özcan CT, Kır T, Çetin M, Fedai T (2013) Türk hemşirelik öğrencilerinde Purdue pegboard beceriklilik testi ile sınıf başarı sıralamasının korelâsyonu. (Correlation of Purdue pegboard dexterity test scores with class rank of Turkish nursing students). TAF Preventive Medicine Bulletin 12(6): 619-624.

Başara BB, Çağlar İS, Aygun A, Özdemir TA, Kulali B, Uzun SB et al. (2019) The Ministry of Health of Turkey health statistics yearbook 2018. In BB Başara, İS Çağlar, A Aygün, TA Özdemir (eds), 1-269. Ankara: Republic of Turkey Ministry of Health General Directorate of Health Information Systems.

Bensel CK (1993) The effects of various thicknesses of chemical protective gloves on manual dexterity. Ergonomics 36(6): 687-696.

Beydoğan A (2008) Serebrovaskuler olay geçiren hastalarda volar statik el-el bileği ortez kullaniminin etkinligi $i$. (The efficiency of the use of volar static hand-wrist orthosis in the patients with cerebrovascular case). Retrieved from: https://bit.ly/2BgkxwA.

Çakıt E (2008) El becerisine etki eden faktörlerin değerlendirilmesine yönelik bulanık mantık yaklaşımı. (Fuzzy logic approach to determine the factors affecting hand dexterity). Master Thesis. Turkey: University of Çukurova.

Çalışkan S, Gökbel H (1997) El tercihi ile el becerisi ve el kavrama kuvveti arasındaki ilişkiler. (Relationships between hand preference and hand skill and hand grip force). Genel Tip Dergisi 7(4): 195-197.

D'Hondt E, Deforche B, De Bourdeaudhuij I, Lenoir M (2009) Relationship between motor skill and body mass index in 5-to 10-year-old children. Adapted Physical Activity Quarterly 26(1): 21-37.

Demirel P (2005) El antropometrik ölçümleri ve el kavrama kuvvetinin farklı spor branşlarında karşılaştırılması. (Comparison of hand anthropometric measurements and grip strength in different sports branches). Master Thesis. Turkey: University of Zonguldak Karaelmas. 
Denat Y, Eşer İ (2006) Hemşirelikte psikomotor beceri eğitimi. (The education for psychomotor skills in nursing). Hospital \& Life Hastane Forumu 1(2): 55-60.

Doğan N (2012) Mesleklere göre el fonksiyonlarının değerlendirilmesi. (Evaluation of hand functions according to professions). Master Thesis. Turkey: University of İstanbul Bilim.

Dokuztuğ F, Dilşen G, Uğurlu D (1991) 20-84 yaş grubu arasındaki sağliklı kişilerde el fonksiyonlarının değerlendirilmesi. (Evaluation of hand functions in 20-84 age group of healthy individuals). Acta Orthopaedica et Traumatologica Turcica 25(2): 104 106.

Drabek T, Boucek CD, Buffington CW (2010). Wearing the wrong size latex surgical gloves impairs manual dexterity. Journal of Occupational and Environmental Hygiene 7(3): 152-155.

Fry DE, Harris WE, Kohnke EN, Twomey CL (2010) Influence of double-gloving on manual dexterity and tactile sensation of surgeons. Journal of the American College of Surgeons 210(3): 325-330.

Gansky SA, Pritchard H, Kahl E, Mendoza D, Bird W, Miller AJ et al. (2004) Reliability and validity of a manual dexterity test to predict preclinical grades. Journal of Dental Education 68(9): 985-994.

Genç A, Altuntaşoğlu B, Özcan A (2002) Müzisyen ve müzisyen olmayan olgularda el fonksiyonlarının karşılaştırılması. (Comparison of hand functions in musicians and non-musicians). Fizyoterapi Rehabilitasyon 13(3): 124-128.

Giuliani M, Lajolo C, Clemente L, Querqui A, Viotti R, Boari A et al. (2007) Is manual dexterity essential in the selection of dental students? British Dental Journal 203(3): $149-155$.

Goldsmith M, Stewart L, Ferguson L (2006) Peer learning partnership: an innovative strategy to enhance skill acquisition in nursing students. Nurse Education Today 26(2): 123-130.

Gündoğan NÜ, Yazıcı AC, Özmen İ, Koçtekin B, Şimşek A (2009) Kısa süreli motor aktivitenin el beceri hızı üzerine etkisi. (Effect of short-term motor activity on hand skill rate). Dirim Tip Gazetesi 84(4): 115-124.

Higgins J, Mayo NE, Desrosiers J, Salbach NM, Ahmed S (2005). Upper-limb function and recovery in the acute phase poststroke. Journal of Rehabilitation Research \& Development 42(1): 65-67.

İlmezli Ö (2011) Gürültünün el becerisi üzerine etkisi. (The effect of noise on manual dexterity). Master Thesis. Turkey: University of Dokuz Eylül.

Kuzgun H, Denat Y (2020) The manual dexterity of nursing students and factors that affect it. International Journal of Occupational Safety and Ergonomics 26(1): 9-14.

Lafayette Instrument (2015) Purdue pegboard test user instructions. Model 32020A. Retrieved from: http://www.limef.com/downloads/MAN-32020A-forpdf-rev0.pdf. [Accessed: 1 September 2012].

Mamaklı S (2010) Mesleksel beceri eğitiminde yeterlilik kaybı. (Competence loss in clinical skills training). Master Thesis. Turkey: University of Akdeniz.

Mete S, Uysal N (2009) Hemşirelik mesleksel beceri eğitiminde bir model uygulaması. (Implementation of an education model for nursing skills development). Dokuz Eylül Üniversitesi Hemşirelik Yüksekokulu Elektronik Dergisi 2(3): 115-123.

Moore KD (2001) Öğretim becerileri. (Teaching skills). N Kaya (trans), E Altıntaş (ed). Istanbul: Atlas Bookstore.

Morgan R (2006) Using clinical skills laboratories to promote theory-practice integration during first practice placement: an Irish perspective. Journal of Clinical Nursing 15(2): 155-161. 
National Association of EMS Educators (2002) National guldelines for educating EMS instructors. Module 17: Teaching Psikomotor Skills. Retrieved from: https://bit.ly/2 BiGdbo. [Accessed: 21 May 2014].

Neiburger EJ (1992) Latex gloves and manual dexterity, a study of 50 Midwest dentists. The New York State Dental Journal 58(1): 24-28.

Ojimba JI, Ferguson MB, Weber HP (2004) Evaluation of third year dental students hand skill levels. Keynote Address and Clinical Practice, Feedback and Assessment, The IADR/AADR/CADR $82^{\text {nd }}$ General Session.

Ölçücü B, Canikli A, Ağaoğlu YS, Erzurumluoğlu A (2010) 10-14 Yaş çocuklarda tenis becerisinin gelişimine etki eden faktörlerin değerlendirilmesi. (Evaluation of factors affected on improvements of the tennis skills in children 10-14 years old). Beden Eğitimi ve Spor Bilimleri Dergisi 12(2): 1-11.

Orbak R, Tezel A, Canakci V, Tan U (2002) Right-and left-handed dentists using rightand left-sided dental chairs in treatment of calculus. International Journal of Neuroscience 112(1): 15-30.

Sawyer J, Bennett A (2006) Comparing the level of dexterity offered by latex and nitrile safeskin gloves. Annals of Occupational Hygiene 50(3): 289-296.

Senemoğlu N (2011) Gelişim ögrrenme ve ögretim kuramdan uygulamaya. (Devolopment, learning and teaching: from theory to practice). Ankara: Pegem Akademi Publications.

Sezer N, Köseoğlu F, Kibar S (2009) Hemiplejik hastalarda elde fonksiyonel aktivite düzeyi ve el bileği kemik mineral yoğunluğu ilişkisi: ön çalışma. (Association of hand functional activity level and bone mineral density of wrist in patients with hemiplegia: preliminary study). Fiziksel Tip ve Rehabilitasyon Bilimleri Dergisi 12(Feb): 67-73.

Soyupek F, Bölükbaşı N, Yorgancioğlu ZR, Gökoğlu F (2006) The effect of aerobic exercise on hand strength and dexterity of patients with coronary artery disease. Turkish Journal of Physical Medicine and Rehabilitation 52(2): 72-75.

Tiffin J, Asher EJ (1948) The Purdue pegboard: norms and studies of reliability and validity. Journal of Applied Psychology 32(3): 234-247.

Wagner CH (1988) The pianist's hand: anthropometry and biomechanics. Ergonomics 31(1): 97-131.

Weinstein P, Kiyak HA, Milgrom P, Ratener P, Morrison K (1979) Manual dexterity as a predictor of quality of care among dental practitioners. Journal of Dental Education 43(3): 165-169.

Yücel H, Bumin G (2010) El fonksiyonundaki yaşa bağlı değişimin cinsiyete gore incelenmesi. (Investigation of age related dexterity change according to gender). Firat Üniv Sağllk Bilim Derg Tip 24(1): 9-12.

Yücel H, Kayıhan H (2008) Elin fiziksel özelliklerinin el fonksiyonu üzerine etkileri. (Effects of hand physical features on hand function). Fizyoterapi Rehabilitasyon 19(1): 24-29. 
